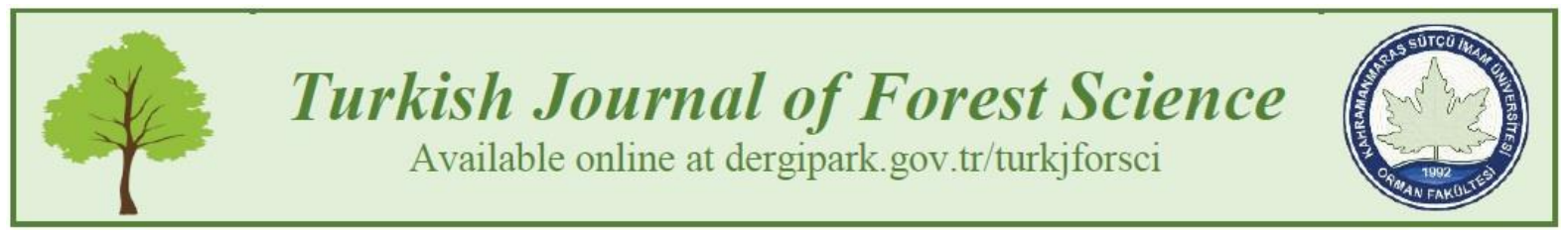

\title{
INVESTIGATION OF HEAVY METAL CONCENTRATIONS IN SOIL CAUSED BY KASTAMONU CITY WILD STORAGE DUMPSITE
}

\author{
Gamze SAVACI ${ }^{1, *}$ Çağatay ÖKSÜZ ${ }^{1}$ \\ ${ }^{1}$ Department of Forest Engineering, Faculty of Forestry, University of Kastamonu, Kastamonu \\ *Corresponding author: gsavaci@kastamonu.edu.tr
}

Gamze SAVACI: https://orcid.org/0000-0003-4685-2797

Çağatay ÖKSÜZ: https://orcid.org/0000-0003-4900-8655

Please cite this article as: Savacı, G. \& Öksüz, Ç. (2020) Investigation of heavy metal concentrations in soil caused by Kastamonu city wild storage dumpsite. Turkish Journal of Forest Science, 4(1), 26-39

\author{
ESER BILGISI / ARTICLE INFO \\ Araştırma Makalesi / Research Article \\ Gelis 15 Mart 2020 / Received 15 March 2020 \\ Duzeltmelerin gelisi 19 Nisan 2020 / Received in revised form 19 April 2020 \\ Kabul 21 Nisan 2020 / Accepted 21 April 2020 \\ Yayımlanma 30 Nisan 2020 / Published online 30 April 2020
}

\begin{abstract}
The aim of this study was to reveal the effects of domestic dumpsite on the some soil chemical properties in the surface soils in Kastamonu city. The soil samples were collected from the 5 different distances namely; Very adjacent (VA), Adjacent (A), Middle (M), Far (F) and Very far (VF). The results showed that the accumulation of heavy metal in the soil varied significantly with the distances. Among the heavy metals, the concentrations of $\mathrm{Co}, \mathrm{Cr}, \mathrm{Cu}$ (only A and VA), Zn (only A and VA), Ni (except for M) exceeded the Maximum Allowable Limit (MAL) for Turkey values. However, the concentrations of Mo, $\mathrm{Pb}$ and $\mathrm{Cd}$ were below the MAL limit values. When all results are considered, it can be stated that the waste dumpsites can negatively affect the environment. Therefore, we make sure that the dumped materials should be concentrated and recycled in order to decrease the amount of heavy metals in the dumpsites and in the soils around the dumpsites. In addition, phytoremediation, which is all the remediation technique available for metal contaminated soils, is the most costly, environmentally friendly and easy to apply. Phytoremediation can be used to remove, displace or reduce contaminants from soil by using plants that hyperaccumulate these contaminants.
\end{abstract}

Keywords: Heavy metal concentration, dumpsite, contamination, Kastamonu

\section{KASTAMONU İLİ VAHŞİ DEPOLAMA ALANI TOPRAKLARINDA AĞIR METAL KONSANTRASYONLARININ INCELENMESI}

ÖZET: $\mathrm{Bu}$ çalışmanın amacı, Kastomonu ilinde yer alan evsel nitelikli çöp sahası topraklarının bazı kimyasal özellikleri üzerindeki etkileri ortaya konulmaya çalışılmıştır. Şehir çöplüğüne yakınlık-uzaklık mesafesine göre Çok yakın (ÇY), Yakın (Y), Orta (O) Uzak (U) ve Çok uzak (ÇU) şeklinde 5 farklı mesafeden toprak örnekleri toplanmıştır. Sonuçlar topraktaki ağır metal birikiminin mesafelere göre önemli ölçüde değiştiğini göstermiştir. Ağır metal konsantrasyonlarından $\mathrm{Co}, \mathrm{Cr}, \mathrm{Cu}$ (sadece $\mathrm{Y}$ ve ÇY), $\mathrm{Zn}$ (sadece $\mathrm{Y}$ ve ÇY) ile Ni (O 
hariç) konsantrasyonları, Türkiye değerleri için izin verilen maksimum sınırı (MAL) aşmıştır. Bununla birlikte, $\mathrm{Mo}, \mathrm{Pb}$ ve $\mathrm{Cd}$ konsantrasyonları MAL sınır değerlerinin altındadır. Sonuçlar değerlendirildiğinde, şehir çöplüğü atıkların çevreyi olumsuz yönde etkilediği görülmektedir. $\mathrm{Bu}$ nedenle şehir çöplüğü topraklarında biriken ağır metallerin miktarını azaltmak için bu alana boşaltılan atıkların konsantre edilmesi veya geri dönüştürülmesi etkili olacaktır. Ayrıca metalle kirlenmiş topraklar için iyileştirme tekniğinden birisi olan fitoremediasyon en uygun maliyetli, çevre dostu ve kolay bir uygulamadır. Fitoremediasyon tekniği, bu kirletici maddeleri bünyesinde biriktiren bitkiler kullanılarak kirletici maddelerin topraktan uzaklaştırılması, yer değiştirmesi veya azaltılması sağlanabilir.

Anahtar kelimeler: Ağır metal konsantrasyonu, şehir çöplüğü, kirlilik, Kastamonu

\section{INTRODUCTION}

The municipal garbage area is one of the most common ways to dispose of urban solid wastes in the world (Xiaoli et al., 2007). Increasing human activity both industrial and domestic causes the increase of waste volume produced from time to time. Most waste is directly discharged into the environment without any intervention. As a result, pollution that harms people and nature occurs. It is the soil pollution that the chemicals enter and change in the natural soil environment (Artiningsih et al., 2018). The factors that cause toxic metal to be included in the contaminant group are due to the nondegradable and easily absorbed properties of the heavy metals ( $\mathrm{Ni}, \mathrm{Co}, \mathrm{Cr}, \mathrm{Cd}, \mathrm{Pb}, \mathrm{Cu}, \mathrm{Zn}, \mathrm{Mo}$ etc.). Tatsi \& Zouboulis (2002) noted that incorrect collection, separation, and disposal applications of domestic solid waste can produce leachates containing high concentrations of ammonium, organic matter, and heavy metal. Uncontrolled storage area is very dangerous for people health and environment (Sakawi et al., 2017).

The total domestic waste disposal in Turkey is estimated to be approximately 27 million tons in 2006. Sixty-four percent (64\%) of municipal waste is maintained through regular storage, $30 \%$ by wild storage (uncontrolled storage), and $6 \%$ by recycling. Thirty percent (30\%) of the waste collected in municipalities is plastic, $9.7 \%$ metal, $40.7 \%$ paper and cardboard, $10.9 \%$ glass, $2 \%$ wood and $6.7 \%$ composite. According to the Turkey Statistical Institute (TÜIK 2017), the amount of municipal waste has increased from 17.76 million tons in 1994 to 31.58 million tons in 2016. According to the data of the Ministry of Environment and Urbanization in 2017 , the ratio of the population served by regular storage facilities to the total municipal population is $74 \%$. The Kastamonu Environmental Status Report has shown that $26 \%$ of urban waste is organic waste, $5 \%$ glass waste, $10 \%$ paper-cardboard, $4 \%$ plastic waste, $6 \%$ metals, $1 \%$ composites, $12 \%$ inert materials, $19 \%$ the functions smaller than $10 \mathrm{~mm}$ and $13 \%$ the other categories (Anonim, 2014).

The objectives of the present study were to (1) determine the concentrations of 8 heavy metal $(\mathrm{Ni}, \mathrm{Co}, \mathrm{Cr}, \mathrm{Cd}, \mathrm{Pb}, \mathrm{Cu}, \mathrm{Zn}$ and $\mathrm{Mo}$ ) in the soils around the city dumpsite of Kastamonu (2) to investigate the effects of different distances to the dumpsite, and (3) asses the concentration and average distribution of heavy metals according to Earth Crust, Maximum Allowable Limit for Turkey (MAL) and Sedimentary-Carbonates Rocks values. Turkey has standard Regulation on Control of Soil Pollution for heavy metal concentration in the soil (Anonim 2001). Therefore, the results of this study will be compared to the Regulation on Control of Soil Pollution and Earth Crust values. 


\section{Study Area}

\section{MATERIAL AND METHODS}

This study was conducted in City Wild Storage Dumpsite, located in the north part of Kastamonu province, northwest Turkey $\left(41^{\circ} 25^{\prime} 16^{\prime \prime} \mathrm{N}, 33^{\circ} 45^{\prime} 44^{\prime \prime}\right.$ E). This study area was 9 $\mathrm{km}$ away from the city center and covered an area of approximately $70000 \mathrm{~m}^{2}$ and a depth of approximately $25 \mathrm{~m}$ (Fig. 1). The elevation was $863 \mathrm{~m}$. a.s.l. and the capacity of the garbage dump was $180.000 \mathrm{~m}^{3}$ (KASMIB, 2018).

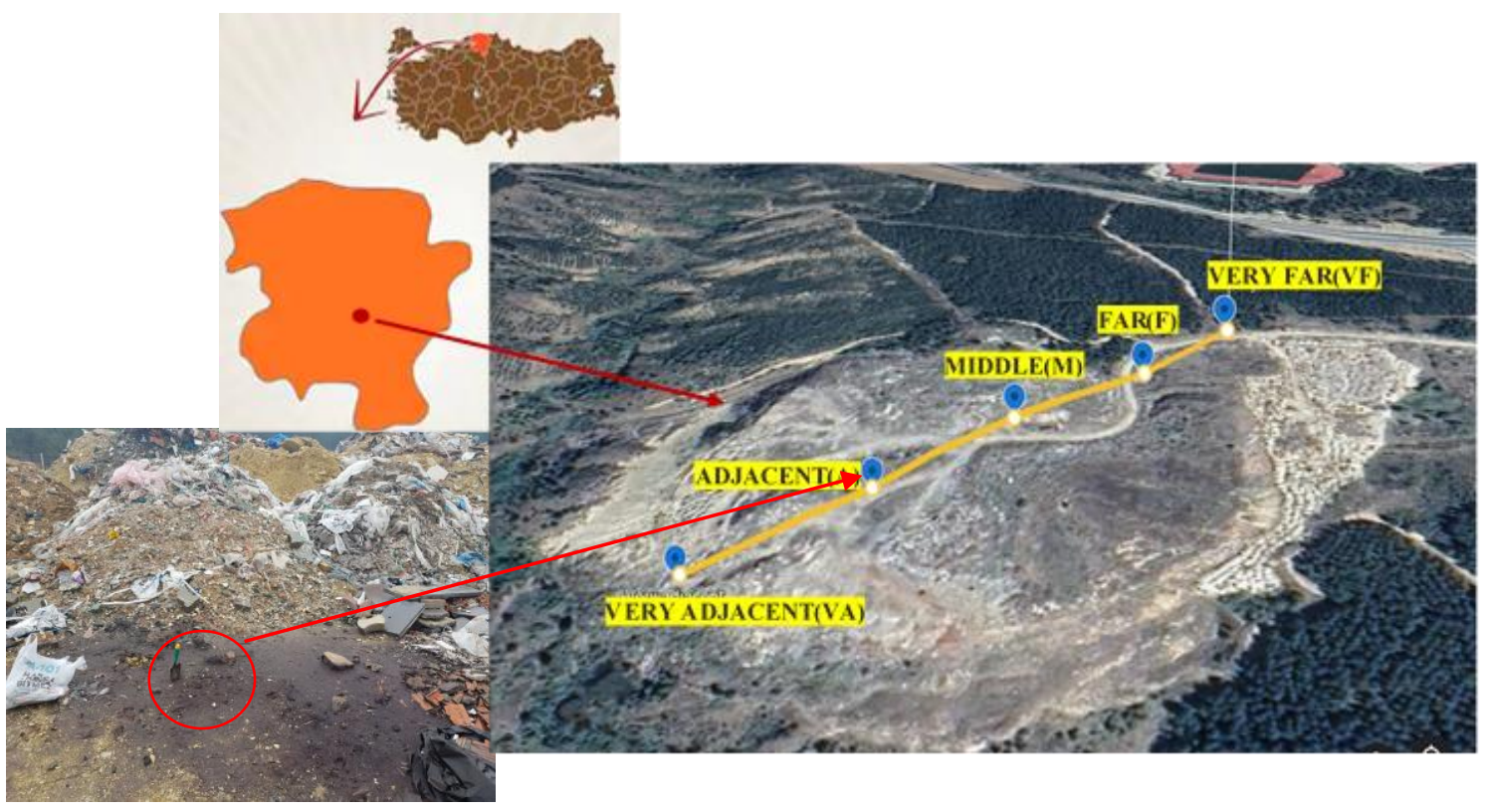

Figure 1. Location of the Study Site

According to the geology maps by the General Directorate of Mineral Research and Exploration, the bedrock of dumpsite is mostly dominated by sedimentary rocks, medium to thick bedded, abundant jointed, gray-beige colored, massive structure, Eocene-bearing neritic limestone (Akbaş et al., 2015). The soil type presents the characteristics of brown forest soil (Anonim, 1990). The characteristics of such soils are loamy or fine-structured, high base saturation (more than 50\%) and high biological activity. The soil is calcareous and the soil $\mathrm{pH}$ varies from 8 to 9 .

The study area is characteristic to Black Sea climate with winters, warm and rainy, summer months, hot but not arid in the region. According to the weather data for 2008-2019 (Kastamonu Meteorology Station at $800 \mathrm{~m}$ a.s.1.), mean annual precipitation is $623.6 \mathrm{~mm}$, with the highest amount in June $(122.5 \mathrm{~mm})$, and the lowest amount in October $(24.8 \mathrm{~mm})$, while mean annual temperature is $10.4^{\circ} \mathrm{C}$, with the highest month in August $20.7^{\circ} \mathrm{C}$ and the lowest month in January $-0.8^{\circ} \mathrm{C}$ (DMİ, 2019).

\section{Sample Collection and Analysis}

Soil samples were taken from 5 different locations away from the dumping site, with the distance at least $30 \mathrm{~m}$ each other namely; Very adjacent (VA), Adjacent (A), Middle (M), Far (F) and Very far (VF). The area of the study is approximately $70000 \mathrm{~m}^{2}$ (L: $300 \mathrm{~m}$ and W: 
$250 \mathrm{~m}$ ), but it was studied at 5 different points in a $180 \mathrm{~m}$ long area due to the fact that the pile of rubble in the land is excessive and has a rough terrain structure (Fig. 1). A total of 15 soil samples, with three replicate each distance, were taken from a depth of $10 \mathrm{~cm}$ using soil core device with an inner diameter of $5 \mathrm{~cm}$. In addition, the soil samples could not be taken too much since the city dump is in group and group garbage dump (Fig. 1). The moist field samples were sieved to remove stones, roots and macrofauna and collected to give a single representative soil sample for each distance. The samples were placed into labelled polythene bags and taken to the laboratory for chemical analysis. Soils were air dried for two weeks, ground and sieved through a $2 \mathrm{~mm}$ sieve.

Soil $\mathrm{pH}\left(\mathrm{H}_{2} \mathrm{O}\right)$ and heavy metal concentrations were determined. Soil $\mathrm{pH}\left(\mathrm{H}_{2} \mathrm{O}\right)$ was measured in a 1:2.5 mixture of distilled water and soil by $\mathrm{pH}$ meter (LaMotte $\mathrm{pH} 5$ series meter) after equilibration for $1 \mathrm{~h}$ in solution (Jackson, 1962). Determination of heavy metal concentration in the soils was analyzed using XRF (X-ray Fluorescence Spectrometer). Soil analyses were triplicate.

References of heavy metal concentrations with the standard Regulation on Control of Soil Pollution for Turkey are given in Table 1. These standards were marked as Maximum Allowable Limit (MAL) and determined heavy metal concentrations in the soil (Anonim, 2001). In addition, the results of heavy metal concentrations have compared to distribution of the elements in the Earth's Crust (Turekian \& Wedepohl, 1961).

Table 1. The distribution of the heavy metal concentrations compared to Turkey and Earth's Crust

\begin{tabular}{lcc}
\hline $\begin{array}{c}\text { Heavy Metal } \\
\text { concentration }\end{array}$ & $\begin{array}{c}\text { pH>6 (MAL) } \\
\text { oven-dried soil } \\
\left(\mathbf{~ m g ~ k g ~}^{-1}\right)\end{array}$ & $\begin{array}{c}\text { Earth's Crust } \\
\text { (Sedimentary-Carbonates) } \\
\left(\mathbf{~ m g ~ k g} \mathbf{~}^{-1}\right)\end{array}$ \\
\hline Nickel (Ni) & 75 & 20 \\
Cobalt (Co) & 20 & 0.1 \\
Cadmium (Cd) & 3 & 0.035 \\
Crome (Cr) & 100 & 11 \\
Lead (Pb) & 300 & 9 \\
Copper (Cu) & 140 & 4 \\
Zinc (Zn) & 300 & 20 \\
Molybdenum (Mo) & 10 & 0.4 \\
\hline
\end{tabular}

\section{Statistical Analysis}

An Analysis of variance (ANOVA) has been carried out for analyzing the effects of the distances on the soil heavy metal concentrations using the SPSS program (Version 22 for Windows). Following the results of ANOVAs, Tukey's Honestly Significant Difference (HSD) test $(\alpha=0.05)$ was used for multiple comparisons to examine the significant response of the heavy metal concentrations to the distances. The correlation coefficient was also used to measure the strength of inter-relationship among the heavy metals. 


\section{RESULTS AND DISCUSSION}

As is known, data must fulfill two assumptions in order to apply the analysis of variance. The data should have minimum interval scale and show a normal distribution. Therefore, fitness of data to normal distribution was checked through the Shapiro-Wilk one sample test. It was found that the the majority of heavy metal concentrations demonstrated normal distribution $(\mathrm{P}>0.05)$ (Table 2).

Table 2. The normality distribution with Shapiro-Wilk analysis

\begin{tabular}{lcccc}
\hline $\begin{array}{c}\text { Heavy Metal } \\
\text { Concentration }\end{array}$ & $\mathbf{N}$ & $\mathbf{M} \pm \mathbf{S E}$ & Statistic & $\mathbf{P}$ \\
\hline nickel & 15 & $264.40 \pm 93.98$ & .533 & $.000^{*}$ \\
cobalt & 15 & $29.37 \pm 1.44$ & .948 & .499 \\
crome & 15 & $122.71 \pm 2.16$ & .899 & .091 \\
cadmium & 15 & $2.00 \pm 0.05$ & .958 & .659 \\
lead & 15 & $39.513 \pm 5.12$ & .918 & .180 \\
copper & 15 & $252.75 \pm 78.22$ & .742 & $.001^{*}$ \\
Zinc & 15 & $286.68 \pm 74.31$ & .764 & $.001^{*}$ \\
molybdenum & 15 & $1.523 \pm 0.19$ & .886 & .059 \\
\hline${ }^{*}<0.05$ & & & &
\end{tabular}

\section{Heavy metal concentrations}

The variation in mean Ni concentration with the distances in the soil is shown in Fig. 2. The Maximum Allowable Limit in Turkey (MAL) for $\mathrm{Ni}$ is $75 \mathrm{mg} \mathrm{kg}^{-1}$ (Anonim, 2001). The adjacent distance (A) had the highest $\mathrm{Ni}$ concentration $\left(967.2 \pm 78.9 \mathrm{mg} \mathrm{kg}^{-1}\right)$, whereas the middle distance $(\mathrm{M})$ had the lowest $\mathrm{Ni}$ concentration $\left(64.1 \pm 3.82 \mathrm{mg} \mathrm{kg}^{-1}\right)$, which was the only Ni concentration below the MAL value in the soil. The other distances also had Ni concentration above the MAL values (Fig. 2). Najib et al. (2012) found that the concentration of Ni was $30 \mathrm{mg} \mathrm{kg}^{-1}$ in the Kangar dumping site. Similarly, Tumuklu et al. (2007) reported that the concentration of $\mathrm{Ni}$ increased with decreasing the distance to the Niğde city garbage dumpsite $\left(460 \mathrm{mg} \mathrm{kg}^{-1}\right)$. Olafisoye et al. (2013) reported that $\mathrm{Ni}$ concentration decreased from the top soil $\left(85.43 \pm 0.02 \mathrm{mg} \mathrm{kg}^{-1}\right.$ at $\left.0-15 \mathrm{~cm}\right)$ to the subsoil $\left(35.45 \pm 0.01 \mathrm{mg} \mathrm{kg}^{-1}\right.$ at $\left.15-30 \mathrm{~cm}\right)$. In most countries, $\mathrm{Ni}$ concentrations were found to be over the critical value. The results in this study were in agreement with the study by Adelekan \& Alawode (2011) who found Ni concentration ranging between $18 \mathrm{mg} \mathrm{kg}^{-1}$ and $335 \mathrm{mg} \mathrm{kg}^{-1}$. Turhan et al. (2020) reported that the $\mathrm{Ni}$ concentrations under the agricultural surface soil samples in Kangal varied from 89.5 $\mathrm{mg} \mathrm{kg}-1$ to $971.0 \mathrm{mg} \mathrm{kg}^{-1}$ with an average value of $610.1 \mathrm{mg} \mathrm{kg}^{-1}$.

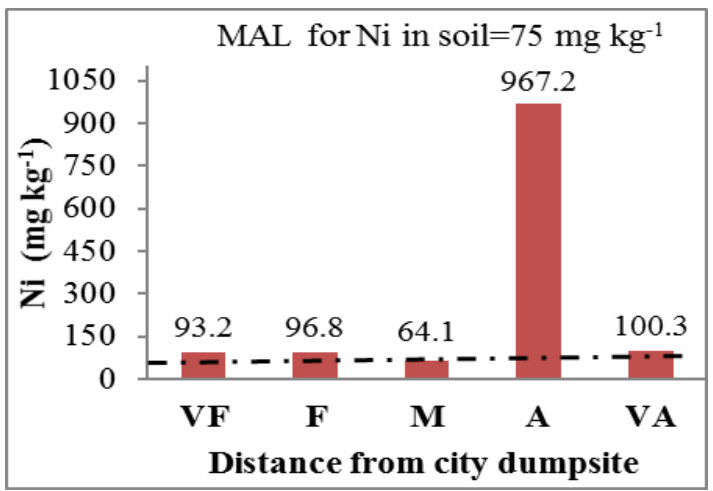

Figure 2. Mean Ni Concentration in the Soils around the Dumpsite 
Mean Co concentration was above the MAL value in the soil (Fig. 3). The highest Co concentration was found in the soil of very far (VF) distance $\left(34.2 \pm 4.24 \mathrm{mg} \mathrm{kg}^{-1}\right)$, whereas the lowest Co concentration was seen in in the soil of the middle (M) distance $(26.1 \pm 4.03 \mathrm{mg}$ $\left.\mathrm{kg}^{-1}\right)$. The lower concentration of Co was also shown by a number of studies. For example, $\mathrm{Lu}$ et al. (2010) found that the concentration of Co at the street dust of Baoji was $15.9 \mathrm{mg} \mathrm{kg}^{-}$ 1 .

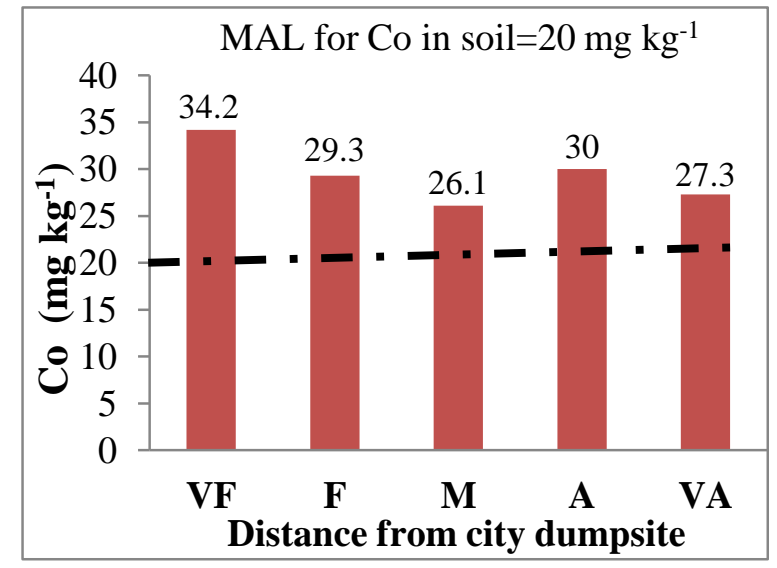

Figure 3. Mean Co Concentration in the Soils around the Dumpsite

Mean Cd concentration from all the distances were under the MAL values (Fig. 4). This result could be due to the lower Cd concentration in the wastes in the dump site. Uba et al. (2008) stated that cadmium had the highest level bioavailability in the dumpsites. In general, the higher concentrations of $\mathrm{Cd}$ in a dumpsite may be attributed to various sources, some of which include automobile tire dust, burning of oil and tyre, plastic wrappings, paints, dyes, and especially, refuse dumps and commercial activities (Ali et al., 2005). Sulaiman et al. (2018) reported that the concentration of $\mathrm{Cd}$ in soil samples of two dumpsites (A and B) varied from $2.20 \mathrm{mg} \mathrm{kg}^{-1}$ to $1.53 \mathrm{mg} \mathrm{kg}^{-1}$. They argued that this variation in $\mathrm{Cd}$ concentration may depend on the types and the compositions of waste at the dumpsites. Asemave \& Anhwange (2012) stated that anthropogenic release of Cd under soils might be as a result to the increase in disposal of $\mathrm{Cd}$ containing substances such as batteries in phones and torches, plastics and other electronic gadgets, to the municipal waste dumpsite. Jafaru et al. (2015) found that the $\mathrm{Cd}$ concentration was higher than $0.73 \mathrm{mg} \mathrm{kg}^{-1}$ in a dumpsite soil in Ghana. Adaikpoh (2013) noted that the average Cd concentration in the dumpsites was $1.18 \mathrm{mg} \mathrm{kg}^{-1}$ and ranged from $<0.001-2.30 \mathrm{mg} \mathrm{kg}^{-1}$ in Imoru. Asemave \& Anhwange (2012) noted that cadmium uptake was high in acids soils and was reduced when the soil was limed. In the present study, the soil $\mathrm{pH}$ was generally alkaline, and this could be the reason that $\mathrm{Cd}$ concentrations were lower in the soil samples of all distances. 


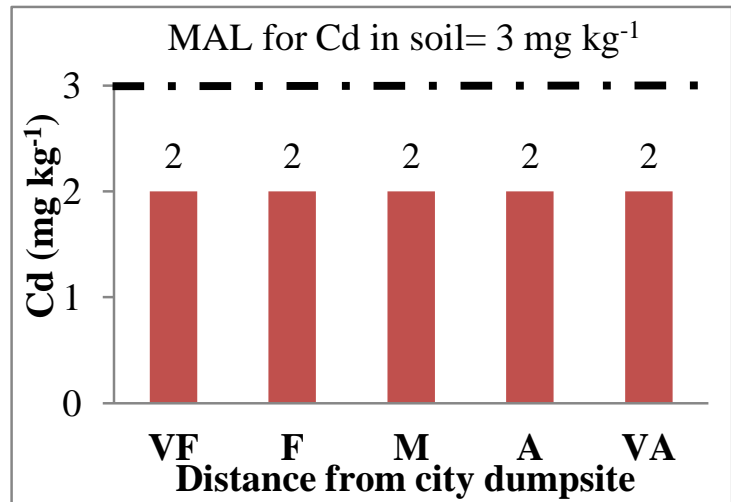

Figure 4. Mean Cd Concentration in the Soils around the Dumpsite

The concentration of $\mathrm{Cr}$ in the soil of all distances showed higher values than the MAL values (100 mg kg-1) (Fig. 5). The soils from the far, middle and adjacent distances showed similar values $\left(128.2 \pm 8.56 \mathrm{mg} \mathrm{kg}^{-1}, 126.1 \pm 8.34 \mathrm{mg} \mathrm{kg}{ }^{-1}\right.$ and $126.3 \pm 7.99 \mathrm{mg} \mathrm{kg}^{-1}$ respectively), but higher values than the soils from the very adjacent $\left(121.4 \pm 15.13 \mathrm{mg} \mathrm{kg}^{-1}\right)$ and the very far distances $\left(111.6 \pm 0.21 \mathrm{mg} \mathrm{kg}^{-1}\right)$. Turhan et al. (2020) noted that $\mathrm{Cr}$ concentrations under soil varied from $125.3 \mathrm{mg} \mathrm{kg}^{-1}$ to $1327.0 \mathrm{mg} \mathrm{kg}^{-1}$ with an average value of $713.2 \mathrm{mg} \mathrm{kg}^{-1}$. Sulaiman et al. (2018) found the lower Cr concentration in one dumpsite A $\left(1.65 \mathrm{mg} \mathrm{kg}^{-1}\right)$ than the other dumpsite $\mathrm{B}\left(2.16 \mathrm{mg} \mathrm{kg}^{-1}\right)$. The higher $\mathrm{Cr}$ concentrations in the present study could be due to the wastes which had higher $\mathrm{Cr}$ concentrations such as plastic materials, empty paint containers and colored polythene bags. According to Jung et al. (2006), Cr resources under soils can be caused by wastes consisting of lead-chrome batteries, colored polythene bags, disposable plastic materials and empty paint containers.

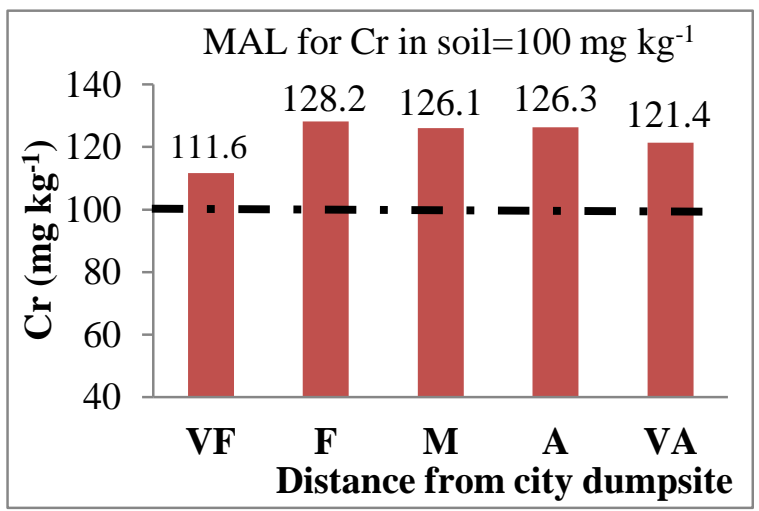

Figure 5. Mean Cr Concentration in the Soils around the Dumpsite

The average concentration of $\mathrm{Pb}$ in the soils of the dumpsite from all distances showed the lowest concentrations compared to the MAL value (300 mg kg-1) (Fig. 6). Among the different distances, the $\mathrm{Pb}$ concentrations were higher from the adjacent $\left(66.3 \pm 4.67 \mathrm{mg} \mathrm{kg}^{-1}\right)$ and the very adjacent distances $\left(55.6 \pm 3.75 \mathrm{mg} \mathrm{kg}^{-1}\right)$ than the soils from the middle, the far and the very far distances (Fig. 6). Ebong et al. (2008) reported that the concentration of $\mathrm{Pb}$ at the dumpsites ranged from $9.46 \mathrm{mg} \mathrm{kg}^{-1}$ to $18.83 \mathrm{mg} \mathrm{kg}^{-1}$ compared to the control sites which ranged from $5.21 \mathrm{mg} \mathrm{kg}^{-1}$ to $7.53 \mathrm{mg} \mathrm{kg}^{-1}$. However, Peramaki \& Decker (2000) found that the concentration of $\mathrm{Pb}$ varied between $8.0 \mathrm{mg} \mathrm{kg}^{-1}$ to $1185 \mathrm{mg} \mathrm{kg}^{-1}$ which were clearly exceeded the MAL limit value. The higher values in $\mathrm{Pb}$ concentrations were also shown by 
Kanmani \& Grandhimathi (2013), ranging from $44.09 \mathrm{mg} \mathrm{kg}^{-1}$ to $178.84 \mathrm{mg} \mathrm{kg}^{-1}$. Madhaven et al. (1989) have stated that $\mathrm{Pb}$ is liable to accumulate in the top soil. They have emphasized that if any city is less populated, it creates little wastes in the dumping sites and consequently it may result in lower $\mathrm{Pb}$ concentrations in the soils around the dumpsite.

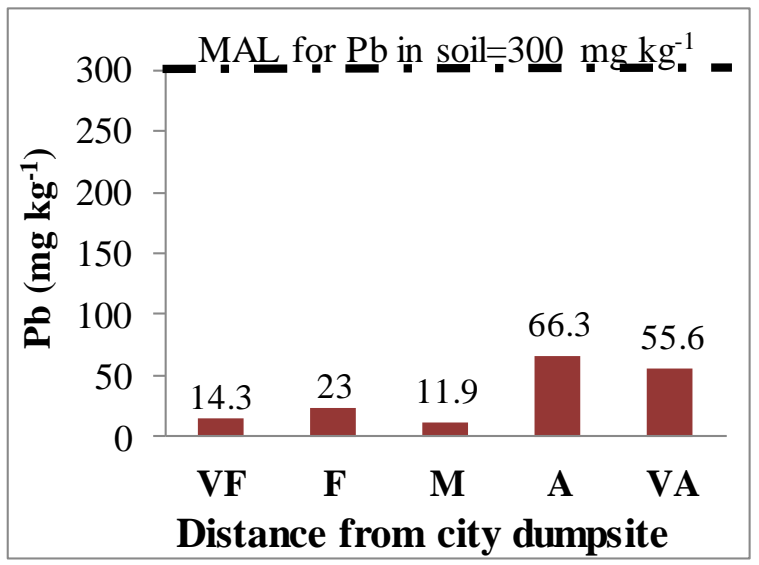

Figure 6. Mean $\mathrm{Pb}$ Concentration in the Soils around the Dumpsite

The soils from the adjacent and very adjacent distances had higher $\mathrm{Cu}$ concentrations compared to the other distances (Fig. 7). The values of $\mathrm{Cu}$ concentrations from the adjacent $\left(636.5 \pm 50.61 \mathrm{mg} \mathrm{kg}^{-1}\right)$ and very adjacent $\left(493.1 \pm 50.4 \mathrm{mg} \mathrm{kg}^{-1}\right)$ distances clearly exceeded the MAL values (140 mg kg-1). Ebong et al. (2008) found lower concentration of $\mathrm{Cu}$ under soils ranged from 2 to100) $\mathrm{mg} \mathrm{kg}^{-1}$. According to Dara (1993), the higher concentration of $\mathrm{Cu}$ at the dumpsite might be connected to biodegradable waste releasing the metallic $\mathrm{Cu}$ into the soil. This can be due to the incorrect disposal of waste lubricants, as well as waste containing electrical and electronic components (Nwachukwu et al., 2011). When the $\mathrm{Cu}$ concentration enters the soil, it usually adheres strongly to organic substances and minerals (Jaradat et al., 2005). As a result, it doesn't go very far after releasing (Adriano, 1986). Perhaps this situation can explain why the higher $\mathrm{Cu}$ content recorded in the soil near the dumpsite than the further away from the dumpsite in this present study.

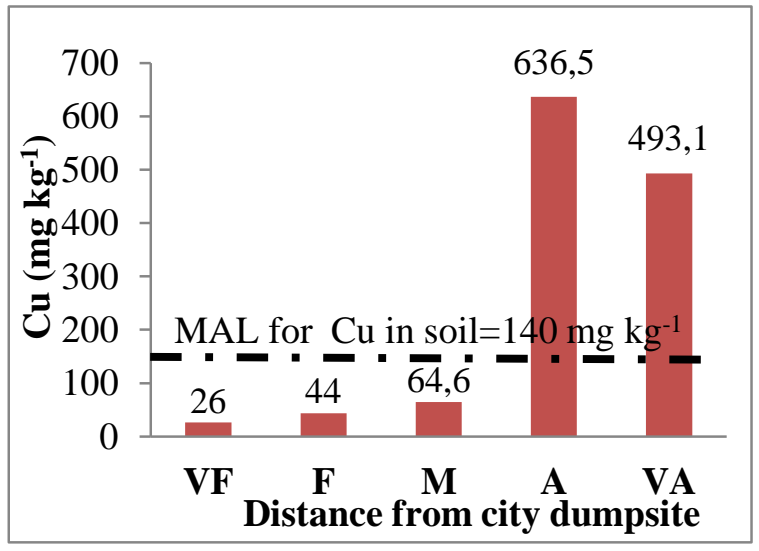

Figure 7. Mean Cu Concentration in the Soils around the Dumpsite

The concentrations of $\mathrm{Zn}$ in top soil of the adjacent $\left(422.9 \pm 4.60 \mathrm{mg} \mathrm{kg}^{-1}\right)$ and the very adjacent distances $\left(760 \pm 24.32 \mathrm{mg} \mathrm{kg}^{-1}\right)$ were higher than the other distances (Fig. 8). The higher concentrations of the adjacent and the very adjacent distances were also over the limit 
value of the MAL for $\mathrm{Zn}$ in the soil (300 mg kg-1). The other distances, however, showed much lower values than the MAL value. Asemave \& Anhwange (2012) also found lower Zn concentration in the soils ranging between $13.82 \mathrm{mg} \mathrm{kg}^{-1}$ to $17.26 \mathrm{mg} \mathrm{kg}^{-1}$ compared to the control sites ranging from $6.32 \mathrm{mg} \mathrm{kg}^{-1}$ to $8.15 \mathrm{mg} \mathrm{kg}^{-1}$. However, a study by Odukoya et al. (2000) showed higher $\mathrm{Zn}$ concentration in the soils ranging from $100.80 \mathrm{mg} \mathrm{kg}^{-1}$ to 226.00 $\mathrm{mg} \mathrm{kg}$. The reason for this change is due to the disposal of high content $\mathrm{Zn}$ waste to the landfill.

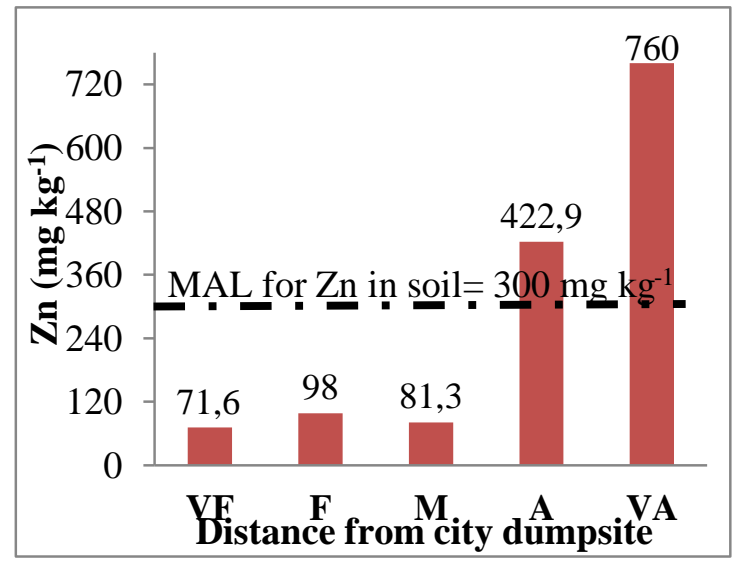

Figure 8. Mean Zn Concentration in the Soils around the Dumpsite

The concentrations of Mo in the soils of the different distances from the dumpsites were very low compared to the MAL value (10 $\mathrm{mg} \mathrm{kg}^{-1}$ ) (Fig. 9). This result indicates that the dumped wastes consisted of less Mo concentration. Similar results were shown by Yalçın \& Çimrin (2019) who stated that there was no heavy metal pollution or lack of Mo in the soil around the dumpsites.

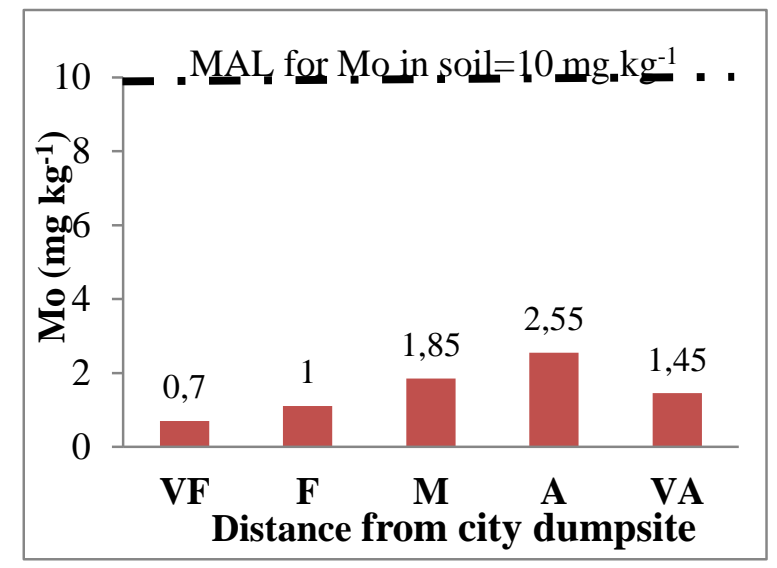

Figure 9. Mean Mo Concentration in the Soils around the Dumpsite

Comparisons the average concentrations of heavy metal in the soils from dumpsite distances are given in Table 3. $\mathrm{Ni}, \mathrm{Pb}, \mathrm{Cu}, \mathrm{Zn}$ and Mo concentrations are the highest value at adjacent (A) and very adjacent (VA) distances. 
Table 3. Sequence of Heavy Metals Concentrations based on the Distances from Dumpsite

\begin{tabular}{lc}
\hline Heavy Metal & Sequence of the distances from dumpsite \\
\hline $\mathrm{Ni}$ & $\mathrm{A}>\mathrm{VA}>\mathrm{F}>\mathrm{VF}>\mathrm{M}$ \\
$\mathrm{Co}$ & $\mathrm{VF}>\mathrm{A}>\mathrm{F}>\mathrm{VA}>\mathrm{M}$ \\
$\mathrm{Cd}$ & $\mathrm{VF}=\mathrm{F}=\mathrm{M}=\mathrm{A}=\mathrm{VA}$ \\
$\mathrm{Cr}$ & $\mathrm{F}>\mathrm{A}>\mathrm{M}>\mathrm{VA}>\mathrm{VF}$ \\
$\mathrm{Pb}$ & $\mathrm{A}>\mathrm{VA}>\mathrm{F}>\mathrm{VF}>\mathrm{M}$ \\
$\mathrm{Cu}$ & $\mathrm{A}>\mathrm{VA}>\mathrm{M}>\mathrm{F}>\mathrm{VF}$ \\
$\mathrm{Zn}$ & $\mathrm{VA}>\mathrm{A}>\mathrm{F}>\mathrm{M}>\mathrm{VF}$ \\
$\mathrm{Mo}$ & $\mathrm{A}>\mathrm{M}>\mathrm{VA}>\mathrm{F}>\mathrm{VF}$ \\
\hline
\end{tabular}

Compared to Earth Crust ratios in sedimentary-carbonated rocks (Turekian \& Wedepohl, 1961), the average Ni concentration is about thirteen times higher than earth's crust average of $20 \mathrm{mg} \mathrm{kg}^{-1}$ (Tab. 1). Similary, Turhan et al. (2020) noted that the average of Ni concentration in the agricultural ultrabasic soils were about ten times higher than the earth's crust average of $58 \mathrm{mg} \mathrm{kg}^{-1}$. Cobalt (Co) concentrations were an average value of $29.37 \mathrm{mg}$ $\mathrm{kg}^{-1}$ (Tab. 2). The average Co concentration was about three hundred times higher than earth's crust average of $0.1 \mathrm{mg} \mathrm{kg}^{-1}$ (Tab. 1). Cadmium (Cd) concentrations in the soil were an average value of $2 \mathrm{mg} \mathrm{kg}^{-1}$ (Tab. 2). The average Cd concentration was about fifty seven times higher than earth's crust average of $0.035 \mathrm{mg} \mathrm{kg}^{-1}$ (Tab. 1). Chrome (Cr) concentrations in the soil were an average value of $122.71 \mathrm{mg} \mathrm{kg}^{-1}$ (Tab. 2). The average $\mathrm{Cr}$ concentration was about eleven times higher than earth's crust average of $11 \mathrm{mg} \mathrm{kg}^{-1}$ (Tab. 1). Similary, Turhan et al. (2020) noted that the average of Cd concentration in the ultrabasic soil were about nine times higher than the earth's crust average of $83 \mathrm{mg} \mathrm{kg}^{-1}$. The average lead $(\mathrm{Pb})$ and molybdenum (Mo) concentrations were about four times higher than the earth's crust average of $9 \mathrm{mg} \mathrm{kg}^{-1}$ and $0.4 \mathrm{mg} \mathrm{kg}^{-1}$, respectively (Tab. 2). Finally, copper $(\mathrm{Cu})$ and zinc ( $\mathrm{Zn})$ concentrations were approximately sixty four times and fourteen times higher than the earth's crust average of $4 \mathrm{mg} \mathrm{kg}^{-1}$ and $20 \mathrm{mg} \mathrm{kg}^{-1}$, respectively (Tab. 1).

\section{Correlation Coefficient Analysis}

Correlation coefficients of Pearson for the heavy metals in the wild storage dumpsite of Kastamonu city are shown in Table 4.

Table 4. The Relationship is a Correlation Analysis between Heavy Metal Concentrations

\begin{tabular}{|c|c|c|c|c|c|c|c|c|}
\hline & $\mathrm{Ni}$ & $\mathrm{Co}$ & $\mathrm{Cr}$ & $\mathrm{Cd}$ & $\mathrm{Pb}$ & $\mathrm{Cu}$ & $\mathrm{Zn}$ & Mo \\
\hline $\mathbf{N i}$ & 1 & & & & & & & \\
\hline Co & $-.694^{* *}$ & 1 & & & & & & \\
\hline $\mathrm{Cr}$ & $.993^{* *}$ & $-.696^{* *}$ & 1 & & & & & \\
\hline Cd & -.056 & .118 & -.050 & 1 & & & & \\
\hline $\mathbf{P b}$ & $.777^{* *}$ & $-.465^{*}$ & $.764^{* *}$ & -.067 & 1 & & & \\
\hline $\mathrm{Cu}$ & $.947^{* *}$ & $-.761^{* *}$ & $.934^{* *}$ & -.067 & $.859^{* *}$ & 1 & & \\
\hline $\mathbf{Z n}$ & $.428^{*}$ & -.336 & $.411^{*}$ & .007 & $.851^{* *}$ & $.647^{* *}$ & 1 & \\
\hline Mo & $.991^{* *}$ & $-.746^{* *}$ & $.985^{* *}$ & -.053 & $.715^{* *}$ & $.934^{* *}$ & .373 & 1 \\
\hline
\end{tabular}

A significantly positive correlation at $\mathrm{P}<0.01$ was found between the elemental pairs $\mathrm{Cr}-\mathrm{Ni}$ $(\mathrm{r}=0.993), \mathrm{Pb}-\mathrm{Ni}(\mathrm{r}=0.777), \mathrm{Cu}-\mathrm{Ni}(\mathrm{r}=0.947), \mathrm{Mo}-\mathrm{Ni}(\mathrm{r}=0.991), \mathrm{Pb}-\mathrm{Cr}(\mathrm{r}=0.764), \mathrm{Cu}-\mathrm{Cr}$ $(\mathrm{r}=0.934), \mathrm{Mo}-\mathrm{Cr}(\mathrm{r}=0.985), \mathrm{Cu}-\mathrm{Pb}(\mathrm{r}=0.859), \mathrm{Zn}-\mathrm{Pb}(\mathrm{r}=0.851), \mathrm{Mo}-\mathrm{Pb}(\mathrm{r}=0.715), \mathrm{Zn}-\mathrm{Cu}$ 
$(\mathrm{r}=0.647)$ and $\mathrm{Mo}-\mathrm{Cu}(\mathrm{r}=0.934)$. Co is also significantly negatively correlated with $\mathrm{Ni}, \mathrm{Cr}$, $\mathrm{Cu}$ and $\mathrm{Mo}$ at $\mathrm{P}<0.01$ different from dumpsite soils (Table 4). $\mathrm{Pb}$ and $\mathrm{Co}$ was negatively correlated $(\mathrm{r}=-0.465)(\mathrm{P}<0.05)$, while $\mathrm{Zn}-\mathrm{Ni}$ and $\mathrm{Zn}-\mathrm{Cr}$ were positively correlated $(\mathrm{P}<0.05)$. However, $\mathrm{Cd}$ did not show any correlation with the other heavy metals. Similary, Tumuklu et al. (2007) reported that there was high level of positive correlation between $\mathrm{Cr}-\mathrm{Ni}(\mathrm{r}=0.824)$ in the Niğde City Garbage dumpsite soils. Yalcin et al. (2007) found that there was moderate positive correlation for $\mathrm{Cr}-\mathrm{Ni}(\mathrm{r}=0.505)$ and $\mathrm{Pb}-\mathrm{Ni}(\mathrm{r}=0.385)$ heavy metals in the soils. Liu et al. (2013) found that there were significant positive correlations between $\mathrm{Cu}-\mathrm{Zn}(\mathrm{r}=0.878$, $\mathrm{p}<0.01), \mathrm{Cu}-\mathrm{Cr}(\mathrm{r}=0.426, \mathrm{p}<0.05)$, and $\mathrm{Cd}-\mathrm{Pb}(\mathrm{r}=0.732, \mathrm{p}<0.01)$. Yalçın \& Çimrin (2019) noted a positive correlation between the $\mathrm{Co}$ and $\mathrm{Ni}(\mathrm{r}=0.52, \mathrm{p}<0.001), \mathrm{Pb}(\mathrm{r}=0.24, \mathrm{p}<0.05)$ and $\mathrm{Fe}(\mathrm{r}=0.34, \mathrm{p}<0.001)$. Costa et al. (2017) investigated the natural content of heavy metals in South Amozon region in Brazil, and found that $\mathrm{Co}$ and $\mathrm{Cd}, \mathrm{Pb}$ and $\mathrm{Fe}$ contents were positively correlated. Yalçın \& Çimrin (2019) also found a significant positive correlation between the Ni-Pb $(r=0.31, \mathrm{p}<0.001)$ and $\mathrm{Pb}-\mathrm{Cu}(\mathrm{r}=0.61, \mathrm{p}<0.001)-\mathrm{Fe}(\mathrm{r}=0.44, \mathrm{p}<0.001$. Liu et al. (2016) noted a positive correlation between the Ni-Pb.

Liu et al. (2013) noted that all heavy metals (except for Pb) relatively low concentrations from 0.1 to $1 \mathrm{~km}$ from the dumpsite. Therefore, they are much lower than that found in the soils in the dumpsite in other countries including Turkey. In this present study, we found serious accumulation of heavy metal except for $\mathrm{Cd}, \mathrm{Pb}$ and $\mathrm{Mo}$ in relation to the different distances. Tumuklu et al. (2007) showed that the heavy metal concentrations in study area soils diminished with distance to the dumpsite. In our study, $\mathrm{Cd}$ and $\mathrm{Pb}$ concentrations regularly showed a decreasing trend with the distance to the dumpsite $(\mathrm{p}<0.05)$. However, $\mathrm{Cu}, \mathrm{Zn}$ and $\mathrm{Cr}$ concentrations did not show same trends (Table 4). This result has indicated that the enrichment of $\mathrm{Cd}$ and $\mathrm{Pb}$ concentrations can be caused by the dumpsite. It is due to the fact that $\mathrm{Cd}$ concentration has the highest mobility and is more susceptible to release than $\mathrm{Zn}, \mathrm{Cu}, \mathrm{Cr}$ or Pb concentrations (Xiao et al., 2005; Prechthai et al., 2008; Liu et al., 2013). In study area, the strong correlation between these heavy metals can be said to increase the contaminants which originates from anthropogenic (Tumuklu et al., 2007).

\section{CONCLUSIONS}

The study has indicated that the concentrations of eight heavy metal $(\mathrm{Ni}, \mathrm{Co}, \mathrm{Cd}, \mathrm{Cr}, \mathrm{Pb}, \mathrm{Cu}$, $\mathrm{Zn}$ and Mo) in the soils around dumpsite in Kastamonu vary significantly with the distances to the dumpsite. Except for $\mathrm{Cd}, \mathrm{Pb}$ and Mo concentrations, the polluted levels of $\mathrm{Ni}$ (except for $\mathrm{M}$ ) $\mathrm{Co}, \mathrm{Cr}, \mathrm{Cu}$ (only A and VA), Zn (only A and VA) exceed the standards of MAL and Turkey Pollutant Standards which could result in eco-toxicological risk. In particular, the concentrations of $\mathrm{Ni}, \mathrm{Cu}$ and $\mathrm{Zn}$ are noted to be highest. This study also clearly indicates that human activities can be a significant factor of heavy metal contamination in the soil. Consequently, phytoremediation techniques such as phytoextraction is more ideal as a method of remediating contaminated soil and water. Future studies should be focused on identify remediating plants that are adapted the local climate and soil conditions, the combined use of more than one phytoremediation approach for the successful remediation of the contaminant area under field conditions. 


\section{ACKNOWLEDGEMENTS}

The article is prepared under the supervision of Assist. Prof. Dr. Gamze SAVACI at Kastamonu University, Graduate School of Natural and Applied Sciences, Department of Forest Engineering between 2014 -2019 by Çağatay ÖKSÜZ and contains a part of the MSc. thesis (Öksüz, 2019).

\section{AUTHOR CONTRIBUTIONS}

Çagatay Oksuz: Taking soil samples in the study area, preparing for analyses of soil samples in the laboratory and writing the manuscript. Gamze Savaci: Evaluating and interpreting the statistical analysis and writing manuscript.

\section{REFERENCES}

Adaikpoh, E. O. (2013), Distribution and enrichment of heavy metals in soils from waste dump sites within Imoru and environs, Southwest, Nigeria. J. Environ. Earth Sci, 3, 4554.http://citeseerx.ist.psu.edu/viewdoc/download?doi=10.1.1.920.2587\&rep=rep1\&typ $\underline{\mathrm{e}=\mathrm{pd}}$

Adelekan, B. A., \& Alawode, A. O. (2011), Contributions of municipal refuse dumps to heavy metals concentrations in soil profile and groundwater in Ibadan Nigeria. Journal of Applied Biosciences, 40, 2727-2737.

Adriano, D. C. (1986), Trace elements in the terrestrial environment.-Springer-Verlag. New York, 533. ISBN 978-1-4757-1907-9 (eBook)

Akbaş, B., Akdeniz, N., Aksay, A., Altun, İ., Balc1, V., Bilginer, E., et al. (2015), Türkiye Jeoloji Haritası. Maden Tetkik ve Arama Genel Müdürlüğü Yayını. Ankara Türkiye. http://yerbilimleri.mta.gov.tr/anasayfa.aspx

Ali, N., Oniye, S. J., Balarabe, M. L., \& Auta, J. (2005), Concentration of Fe, Cu, Cr, Zn, and $\mathrm{Pb}$ in Makera-Drain, Kaduna, Nigeria, ChemClass Journal, 2, 69-73.

Anonim (1990), Topraksu Genel Müdürlügü̈, Türkiye Geliştirilmiş Toprak Haritası Sınıf ve Haritaları, Ankara. (in Turkish publication)

Anonim (2001), Toprak Kirliliğinin Kontrolü Yönetmeligi, 25831 Sayili Resmi Gazetede, Ankara . https://www.resmigazete.gov.tr/eskiler/2001/12/20011210.htm\#3

Anonim (2014), Kastamonu ili 2014 yılı çevre durum raporu. Kastamonu Çevre ve Şehircilik İl Müdürlüğ̈. Kastamonu (in Turkish publication).

Artiningsih, A., Zubair, H., Imran, A. M., \& Widodo, S. (2018), Distribution of Cu metal on the soil around the landfills of Antang, Makassar City. In IOP Conference Series: Earth and Environmental Science (Vol. 175, No. 1, p. 012021). IOP Publishing. DOI:10.1088/1755-1315/175/1/012021

Asemave, K., \& Anhwange, B. A. (2012), Evaluation of heavy metals in waste dumpsites. Germany, Lambert Academic Publishing; ISBN: 978-3-659-37380-0

Costa, R. D. S., Neto, P. P., Campos, M. C. C., do Nascimento, W. B., Do Nascimento, C.W.A., Silva L. S., Cunha, J. M. (2017), Natural contents of heavy metals in soils of the southern Amazonas state, Brazil. Semina: Ciências Agrárias, 38(6), 3499-3514. DOI: $10.5433 / 1679-0359.2017 \mathrm{v} 38 \mathrm{n} 6 \mathrm{p} 3499$

Dara, S.S. (1993), A textbook of environmental chemistry and pollution control. S. Chand \&Company Ltd. Ram Nagar, New Delhi 110055. ISBN:8121908833, 9788121908832 
DMİ (2019), Devlet Meteoroloji İşleri Gn. Md., Kastamonu Meteoroloji İl Müdürlügü̈, Kastamonu Meteoroloji İstasyonu Verileri, 20082018. Kastamonu.

Ebong, G. A., Akpan, M. M., \& Mkpenie, V. N. (2008), Heavy metal contents of municipal and rural dumpsite soils and rate of accumulation by Carica papaya and Talinum triangulare in Uyo, Nigeria. Journal of Chemistry, 5(2), 281-290.

Jackson, M. L. (1962), Soil chemical analysis. (Constable and Company, Ltd: London).

Jafaru, H. M., Dowuona, G. N. N., Adjadeh, T. A., Nartey, E. K., Nude P. M., \& Neina D. (2015), Geochemical assessment of heavy metal pollution as impacted by municipal solid waste at Abloradjei waste dump site, Accra-Ghana. Research Journal of Environmental and Earth Sciences, 7(3), 50-59.

Jaradat, Q. M., Masadeh, A., Zaitoun, M. A., \& Maitah, B. M. (2005), Heavy metal contamination of soil, plant and air of scrapyard of discarded vehicles at Zarqa City, Jordan. Soil \& Sediment Contamination, 14(5), 449-462. DOI: 10.1080/15320380500180507

Jung, C. H., Matsuto, T., \& Tanaka, N. (2006), Flow analysis of metals in a municipal solid waste management system. Waste Management, 26(12), 1337-1348.

Kanmani, S., \& Gandhimathi, R. (2013), Assessment of heavy metal contamination in soil due to leachate migration from an open dumping site. Applied Water Science, 3(1), 193-205. DOI 10.1007/s13201-012-0072-z

KASMİB (2018), Kastamonu ili 2017 yili çevre durum raporu. Kastamonu Çevre ve Şehircilik İl Müdürlüğü. s. 117.

Liu, C., Cui, J., Jiang, G., Chen, X., Wang, L., \& Fang C. (2013), Soil heavy metal pollution assessment near the largest landfill of China. Soil and Sediment Contamination: An International Journal, 22(4), 390-403. DOI: 10.1080/15320383.2013.733447

Liu, Y. R., He, Z. Y., Yang, Z. M., Sun, G. X., \& He, J. Z. (2016), Variability of heavy metal content in soils of typical Tibetan grasslands. Rsc Advances, 6(107), 105398-105405. https://pdfs.semanticscholar.org/3732/be08dca20094f17bf8cf55835cedbe46e96a.pdf

Lu, X., Wang, L., Li, L. Y., Lei, K., Huang, L., \& Kang, D. (2010). Multivariate statistical analysis of heavy metals in street dust of Baoji, NW China. Journal of hazardous materials, 173(1-3), 744-749.

Madhaven, S., Rosenman, K. D., \& Shehata, T. (1989), Lead in soil: maximum permissible levels. Environ. Res. 49, 136-142. https://doi.org/10.1016/S0013-9351(89)80028-3

Najib, N. W., Mohammed, S. A., Ismail, S. H., \& Ahmad, W. A. (2012), Assessment of heavy metal in soil due to human activities in Kangar, Perlis, Malaysia. Int J Civil Environ., 12(6), 28-33.

Nwachukwu, M. A., Feng, H., \& Alinnor, J. (2011), Urban Environmental Pollution 2010: Trace Metal Dispersion in Soil from Auto-Mechanic Village to Urban Residential Areas in Owerri, Nigeria. Procedia Environmental Sciences. 4, 310-322.

Odukoya, O. O., Bamgbose, O., \& Arowolo, T. A. (2000), Heavy metals in top soils of Abeokuta dump sites. Global Journal of Pure and Applied Sciences, 6(4), 651-653. http://dx.doi.org/10.4314/gjpas.v7i3.16273

Öksüz, Ç. (2019), Determination of heavy metal concentration of soil and vegetation the city waste of Kastamonu. MSc Thesis, Kastamonu University, Graduate School of Natural and Applied Sciences, Department of Forest Engineering, s. 90, Turkey.

Olafisoye, O. B., Adefioye, T., \& Osibote, O. A. (2013), Heavy Metals Contamination of Water, Soil, and Plants around an Electronic Waste Dumpsite. Polish journal of environmental studies, 22(5).

Peramaki, L. A., \& Decker, J. F. (2000), Lead in soil and sediment in Iqaluit, Nunavut, Canada and links with human health. Environ. Monitor. and Assess. 63, 329-339. 
Prechthai, T., Padmasri, M., \& Visvanathan, C. (2008), Quality assessment of mined MSW from an open dumpsite for recycling potential. Resources, Conservation and Recycling, 53(1-2), 70-78. https://doi.org/10.1016/j.resconrec.2008.09.002

Sakawi, Z., SA, S. M., Jaafar, O., \& Mahmud, M. (2017), Community perception of odour pollution from landfills. Geografia-Malaysian Journal of Society and Space, 7(3): 1823. http://ejournal.ukm.my/gmjss/article/view/19840/6283

Sulaiman, M. B., Santuraki, A. H., Isa, K. A., \& Oluwasola, O. H. (2018), Geo-accumulation and Contamination Status of Heavy Metals in Selected MSW Dumpsites Soil in Gombe, Nigeria. Bima. J. Sci. Techno, 2(2), 31-40.

Tatsi, A. A., \& Zouboulis, A. I. (2002), A field investigation of the quantity and quality of leachate from a municipal solid waste landfill in a Mediterranean climate (Thessaloniki, Greece). Advances in Environmental Research, 6(3), 207-219. https://doi.org/10.1016/S1093-0191(01)00052-1

TÜİK (Türkiye İstatistik Kurumu Başkanlığı) (2017), Belediye Atık İstatistikleri, 2016. Haber Bülteni, 29/11/2017, Sayı: 24876 (in Turkish publication).

Tumuklu, A., Yalcin, M. G., \& Sonmez, M. (2007), Detection of Heavy Metal Concentrations in Soil Caused by Nigde City Garbage Dump. Polish Journal of Environmental Studies, 16(4): 651-658. http://www.pjoes.com/Detection-of-HeavyMetal-Concentrations-in-Soil-r-nCaused-by-Nigde-City-GarbageDump,88034,0,2.html

Turekian, K. K., \& Wedepohl, K. H. (1961), Distribution of the elements in some major units of the earth's crust. Geological Society of America Bulletin, 72(2): 175-192. https://doi.org/10.1130/0016-7606(1961)72[175:DOTEIS]2.0.CO;2

Turhan, Ş., Garad, A. M. K., Hançerlioğulları, A., Kurnaz, A., Gören, E., Duran, C., Karataşl1, M., Altıkulaç, A., Savacı, G., \& Aydın, A. (2020), Ecological assessment of heavy metals in soil around a coal-fired thermal power plant in Turkey. Environmental Earth Sciences, 79(6), 1-15. https://doi.org/10.1007/s12665-020-8864-1

Uba, S., Uzairu, A., Harrison, G. F. S., Balarabe, M. L., \& Okunola, O. J. (2008), Assessment of heavy metals bioavailability in dumpsites of Zaria Metropolis, Nigeria. African Journal of Biotechnology, 7(2).

Xiao, Z., He, P., \& Shao, L. (2005), Effect of the total amount and speciation of heavy metals on its mobility in municipal solid waste landfill. Environmental chemistry-beijing-, 24(3), 269.

Xiaoli, C., Shimaoka, T., Xianyan, C., Qiang, G., \& Youcai, Z. (2007), Characteristics and mobility of heavy metals in an MSW landfill: Implications in risk assessment and reclamation. Journal of hazardous materials, 144(1-2), 485-491. https://doi.org/10.1016/j.jhazmat.2006.10.056

Yalcin, M. G., Battaloglu, R., Ilhan, S., Tümüklü, A., \& Topuz, D. (2007), Heavy metal contamination along the Nigde-Adana highway, Turkey. Asian Journal of Chemistry, 19(2), 1506.

Yalçın, M., \& Çimrin, K. M. (2019), Determination of Molybdenum Contents and Relation of Some Heavy Metals in the Soil of Meadow-Pasture Terraces Between KirıkhanReyhanl1. Turkish Journal of Agriculture-Food Science and Technology, 7(1), 13-21. https://doi.org/10.24925/turjaf.v7i1.13-21.1997 